\title{
Imagining the Past? Architecture and Public Rituals in Early Modern Lisbon, Madrid and Valladolid*
}

\author{
LAURA FERNÁNDEZ-GONZÁLEZ \\ University of Lincoln
}

\begin{abstract}
This article discusses the application of architectural drawing and 3D modelling as suitable digital heritage methods for the study of ephemeral and residential architecture in sixteenth-century Iberia. Public rituals transformed spaces of social encounter in early modern cities. Learning how these urban spaces were decorated for such rituals is often challenging, for our knowledge of ephemeral displays and the residential architecture that composed the streetscapes of cities can be slim. Visual sources of ephemera, surviving early modern buildings and depictions of streetscapes can at times be scant. However, urban theories on early modern urbanism, theatre and space have demonstrated that ephemeral and permanent residential architecture are crucial for our understanding of festival culture. This paper examines the digital re-creation of the ephemera of the Lisbon ceremonial entry of 1581 through the lens of notions of authenticity in conservation theory and practice. It also explores
\end{abstract}


early modern reforms in residential architecture in Madrid and Valladolid as a vehicule to examine the relationship between ritual and urbanism. This latter case study crucially shows digital recreations aided the identification of primary visual sources. In doing so, this essay problematizes the use of digital heritage visualisation as a tool for the analysis of urban historic environments.

KEYWORDS: Digital Heritage, Architectural Drawing, Philip II of Spain, Habsburg Madrid, Renaissance Lisbon, Festivals, Urbanism and Theatre, Conservation Theory, Ephemeral Architecture, Urban Streetscapes and Public Ritual.

Calendric and non-calendric festivals had a significant impact on the urban reform of early modern cities. The architecture and urban design of cities such as Palermo were transformed in this period to cater for the ceremonial needs of their residents. Ruling elites made strenuous efforts to improve the streetscapes of cities through incentives that aimed to improve the design of residential architecture, particularly building façades. As a result, urban regulations that fostered the adoption of Renaissance design ideals applied to domestic architecture proliferated in this period. ${ }^{1}$ In early

* This article forms part of the project I+D ART-ES 'Apropiaciones e hibridaciones entre las artes plásticas y escénicas en la Edad Moderna', HAR2015-70089P (MINECO/FEDER). Research for this article was made possible thanks to the support of a British Academy/Leverhulme Trust Small Research Grant; the Calouste Gulbenkian Grants for Foreign Researchers and the Re-creating Early Modern Festivals project funded by the Spanish Consulate in Edinburgh, the University of Edinburgh and the Society for Renaissance Study GB. I thank editors and anonymous peer-reviewers for their insightful comments. Drawing and 3D modelling were completed with the assistance of Harry Kirkham and Nick Sharp.

1 Building Regulations and Urban Form, 1200-1900, ed. Terry R. Slater \& Sandra M.G. Pinto (Abingdon: Routledge, 2017). 
modern political thought a city was a theatre of the world and a reflection of the good (or bad) government of the monarch. A city embellished with fine buildings and ample streets would mirror an ordered society. ${ }^{2}$ Cities in the early modern Iberian world were political tableaux, and examining the relationship between public rituals and architecture is key for an understanding of the city as a performative space.

The study of festivals and urbanism, particularly learning how these urban spaces were decorated for festivals, is often challenging, for our knowledge of ephemeral displays and domestic architecture can be slim. This article examines the digital re-creation of the ephemera of the Lisbon ceremonial entry of 1581 through the lens of notions of authenticity in conservation theory and practice. It also explores sixteenth-century reforms in residential architecture in Madrid and Valladolid, which aimed to embellish streets and plazas in the cities where many public rituals were performed. The case study of these cities crucially shows how digital re-creations have aided the identification of primary visual sources. In this way, this essay problematizes the use of digital heritage visualisation as a tool for the analysis of ritual and urbanism.

\section{Drawing, Modelling and Conservation Theory: Ephemera in}

\section{Lisbon, 1581}

In his Microcosmos, or Historie of Man (1627), the English cleric and writer Samuel Purchas (1577?-1626) considered some of the qualities

2 See Giovanni Botero, A Treatise, Concerning the Causes of the Magnificencie and Greatnes of Cities, trans. Robert Peterson (London: Thomas Purfoot for Richard Ockould \& Henry Tomes, 1606). 
historians possessed in the following unflattering terms: 'Though all Historians will not [...] confesse themselves Fellowes in Lying, yet this is a true Historie, Every Man, and therefore every Historian, is a Lyar.'3 Purchas noted that historians wished to ingratiate themselves with their patrons, and early modern festival books share similar issues. ${ }^{4}$ Chroniclers often magnified the efforts made to mount a festival and its success, and descriptions of streetscapes and the ephemera are also problematic. Examining the textual data that recounts the measurements (if given) of ephemeral structures erected in festivals is no less challenging. There are also lavishly illustrated festival books such as the printed book for Philip II of Portugal (III of Spain)'s entry into Lisbon of 1619, which record the ephemera and include images of many of them. ${ }^{5}$ However, for other festivals with arguably equally impressive displays, such as the entry of Philip I of Portugal (II of Spain) into Lisbon of 1581, the printed material lacks illustrations. ${ }^{6}$ Only two of the printed books that describe the entry into Lisbon of 1581, those by the Portuguese author Afonso Guerreiro and the Spanish writer Isidro Velázquez Salmantino, provide a complete (verbal) picture of the processional route and its ephemera.

3 Richard Kagan, Clio and the Crown: The Politics of History in Medieval and Early Modern Spain (Baltimore: John Hopkins University Press: 2010), 1.

4 See Teófilo F. Ruiz, A King Travels: Festive Traditions in Late Medieval and Early Modern Spain (Princeton, 2012).

5 João Baptista Lavanha, Viage de la Catolica Magestas del Rey Don Felipe III [...] a su Reino de Portugal y Relación del Solemne Recibimiento [...] (Madrid: Tomas Iunta, 1622).

6 The two most detailed accounts of the ceremonial entry of 1581 into Lisbon, are: Affonso Guerreiro, Das Festas que se Fizeram na Cidade de Lisboa, na Entrada de el-rei D. Filipe, Primeiro de Portugal (Lisboa: Francisco Correa, 1581) and Isidro Velázquez Salmantino, La Entrada que en el Reino de Portugal hizo la S.C.R.M. de Don Philippe, Invistissimo Rey de las Españas, Segundo de este nombre, Primero de Portugal [...] (Madrid: Manuel de Lyra, 1583). Other accounts of this entry are cited in: Laura FernándezGonzález, 'Negotiating Terms: King Philip I of Portugal and the Ceremonial Entry of 1581 into Lisbon', in Festival Culture in the World of the Spanish Habsburgs, ed. Fernando Checa Cremades \& Laura Fernández-González (Aldershot: Ashgate, 2015), 87-113 (pp. 107-8 n. 6). 
Guerreiro's offers the most detailed architectural descriptions (including the scales for the ephemera). Velázquez Salmantino likewise includes some architectural data which match completely those given by his Portuguese counterpart. The Spaniard may have copied these measurements from his Lusitanian counterpart, whose book was published earlier. However, the level of detail found especially in Guerreiro's book suggests the information might have been given to both writers, as otherwise, measuring each element of every structure would have been an impossible task for anyone who lacked training in architectural surveying. ${ }^{7}$ Differences are also found between the two accounts which reflect the agendas the authors advanced with their texts. ${ }^{8}$ Above all, these two sources reveal the complex position of the city at a time of dynastic change within the kingdom. Through images and texts the ephemeral decorations projected the wishes and demands of the religious and municipal authorities, the foreign communities of merchants, and the local guilds. ${ }^{9}$

My digital visualisation project of the Lisbon entry of 1581 studied both the ephemeral structures and the urban space where

7 A painting of this entry, lost in the fire of 1734, was displayed at the Alcázar in Madrid, see Ángel Marcos de Dios, 'Itinerario hispánico del Chantre de Évora, Manuel Severim de Faria, en 1604', Revista de Estudios Extremeños, 62 (1986), 139-85.

8 Ana Paula Torres Megiani, O Rei Ausente: festa e cultura política nas visitas dos Filipes a Portugal, 1581 e 1619 (São Paulo: Alameda, 2004).

9 Fernando J. Bouza Álvarez, 'Retórica da Imagem Real: Portugal e a Memória Figurada de Filipe II', Penélope: Revista de História e Ciências Sociais, 4 (1990): 19-58; Fernando J. Bouza Álvarez, Imagen y propaganda: capítulos de la historia cultural del reinado de Felipe II (Madrid: Akal, 1998), 58-92; Laura Fernández-González, 'La representación de las naciones en las entradas triunfales de Felipe II y Felipe III en Lisboa (1581-1619)', in Las Corporaciones de Nación en la Monarquía Hispánica (1580-1750): identidad, patronazgo y redes de sociabilidad, ed. Bernardo J. García García \& Óscar Recio Morales (Madrid: Fundación Carlos de Amberes, 2014), 413-50; Fernández-González, 'Negotiating Terms'. 
the festival had taken place. I began to develop graphically the ephemera of the festival to better understand the visual and spatial hierarchies projected in the pageant. ${ }^{10}$ The first part of the project consisted of drawing architectural plans and creating 3D models of the ephemera that reflected the data provided in the accounts. These models were superimposed onto a 3D model of the city. Pioneering aspects of this work include the fact that it is the first time an early modern festival has been re-created digitally. I focus here on two structures which help to explain the scope of the project.

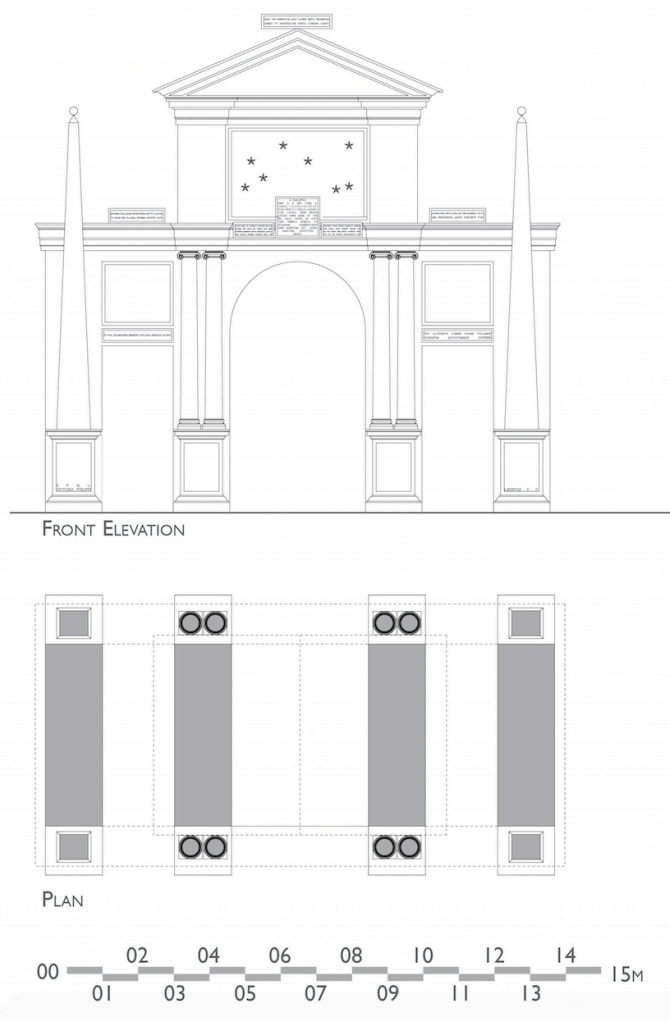

Figure 1. Hypothetical Elevation and Floor Plan of the Arch of the German Merchants erected in Lisbon for the ceremonial entry of Philip I of Portugal (II of Spain) in 1581. Note the drawings do not include colour or the decorative programme that the arch would have displayed. The inclusion of the Latin inscriptions is merely indicative as well. (C) Author, 2010 .

10 For information on the project, including technological aspects, see Laura Fernandez-Gonzalez, 'Virtual Worlds: Visualizing Early Modern Festivals in the Iberian World', Newsletter of the Association of Spanish and Portuguese Historical Studies, 7 (2017), 6-13. 
Guerreiro painstakingly described the Arch of the German Merchants in his account. The passage describing this Arch offers detailed architectural dimensions (figure 1). Architectural data is interspersed within the convoluted description of the decorative programme and the pageant. Excerpts of the textual data that can be drawn to scale, or rather, information which can be 'translated' into an architectural drawing of the Arch of the German Merchants read, for example:

Tinha este arco de grossura trinta \& seys palmos, de largura sesenta \& seys, \& de altura cincoenta \& quatro. Tinha tres portais, hum redondo no meyo de altura trinta palmos, \& de largura dezoto. De cada parte estaua outro portal quadrado, \& cada hum tinha em alto dezoto palmos, \& de vao noue. ${ }^{11}$

The above passage does not encompass the complete decorative programme boasted by the ephemera, nor the full record of architectural measurements Guerreiro provided of the Arch; it does, however, illustrate the basic outline of a grand triumphal arch. He explained that the monumental structure had three gates: the central arch was the highest and the lateral lintelled passages were proportionally smaller. Figure 1 shows the architectural drawing of this arch, and renders the scales provided in the written sources. A close reading of the festival book shines some light on the appearance that the bare structural elements would have had. The digital recreation of the structure, however, excludes the sculpture, paintings and other elements described in the accounts (see Figure 1). The

11 Guerreiro, Das Festas, 15. See also Fernández-González, 'Virtual Worlds', 10. 
resulting diagrams and plans do not convey the decoration and vibrant colours the ephemera would have displayed. In this respect, the project adheres to the London Charter (2009) and Principles of Seville (2011) for the digital visualisation of historic urban environments. The Charter and Principles foster the application of conservation theory and practice in digital heritage and have determined some of the visualisation decisions for the present recreation. ${ }^{12}$ This project is, for example, a 're-creation', as defined in the Charter, as distinct from a 'reconstruction' as understood in conservation theory. For a conservation project to qualify as a reconstruction, a detailed record of the object is required. The textual description of the Lisbon festival of 1581 offers a detailed, yet incomplete, account of the ephemera which could be drawn or modelled. Neither Guerreiro nor Velázquez Salmantino was very specific on colour, for example, and a neutral grey colour has been employed in the digital re-creations instead. ${ }^{13}$ The Charter and Principles foster transparency and authenticity in digital heritage. The inclusion of 'real-life' colours and textures, in re-creating the ephemeral structures erected in Lisbon in 1581, would have been unsuitable and difficult to justify. The resulting drawings and 3D models are, thus, hypothetical visualisations of only a fraction of what the ephemeral displays would have been. Nevertheless, they are significant tools for the intellectual interpretation of the ephemera and the triumphal entry.

12 The London Charter, http://www.londoncharter.org (accessed 9 January 2019); and the Principles of Seville, http://smartheritage.com/seville-principles/seville-principles (accessed 9 January 2019).

13 An example of the project's paradata, see Paradata and Transparency in Virtual Heritage, ed. Anna Bentkowska-Kafel \& Hugh Denard (Aldershot: Ashgate, 2012). 


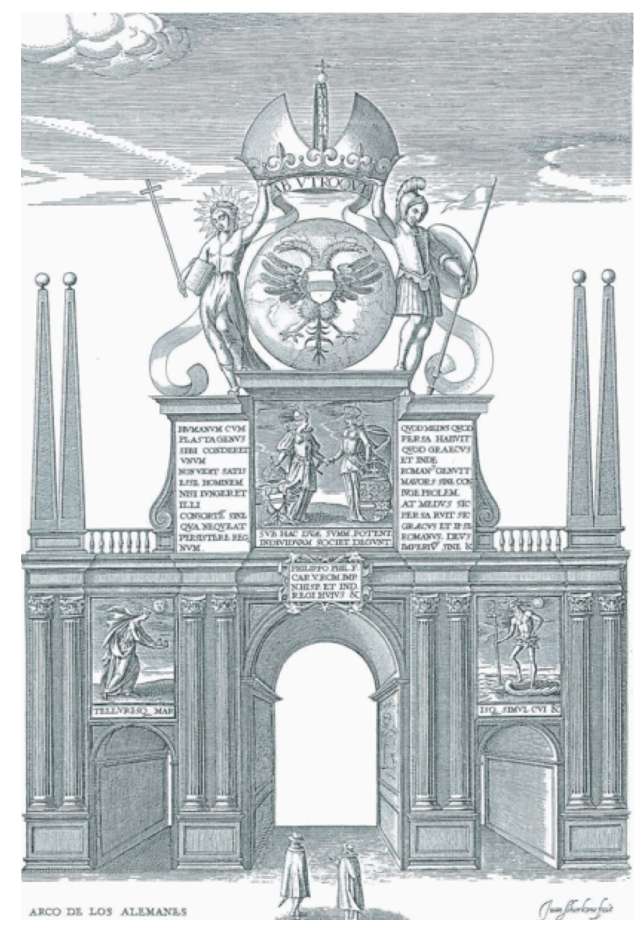

Figure 2 Arch of the German Merchants erected in Lisbon in 1619 for the entry of Philip II of Portugal (III of Spain), found in J.B. Lavanha, Viagem da Catholica Real Magestade del Rey D. Filipe II. N. S. ao Reyno de Portugal e rellação do solene recebimento que nelle se lhe fez, Madrid : por Thomas Iunti, Impressor del Rei N.S., 1622 (1621), Fol. 54 v.

A comparative visual analysis of the re-created 1581 arch and the Arch of the German Merchants erected in Lisbon in 1619 shows the similarities in the structure and also the striking difference that the decorations makes in each case to the bare ephemeral structure (see Figures 1-2). Furthermore, when these two images are compared with the depiction of the Arch of the German Merchants in the Panorama of Lisbon (c. 1620-1622), now at Weilburg Castle, the contrast is clear. ${ }^{14}$ The vibrant colour in the canvas provides a dimension to the arch that the verbal accounts lack and, consequently, the drawings and 3D model cannot incorporate (see Figures. 1-3).

14 I am grateful to Pedro Flor (Instituto de História da Arte, Universidade NOVA, Lisboa) for sharing findings of a research project he coordinated which demonstrates that the canvas dates from c.1620-1622. Analysis of the iconography of Lisbon and photographic and laboratory examinations carried out by Labóratorio HERCULES, Universidade de Évora, coordinated by António Candeias, have confirmed the findings. 


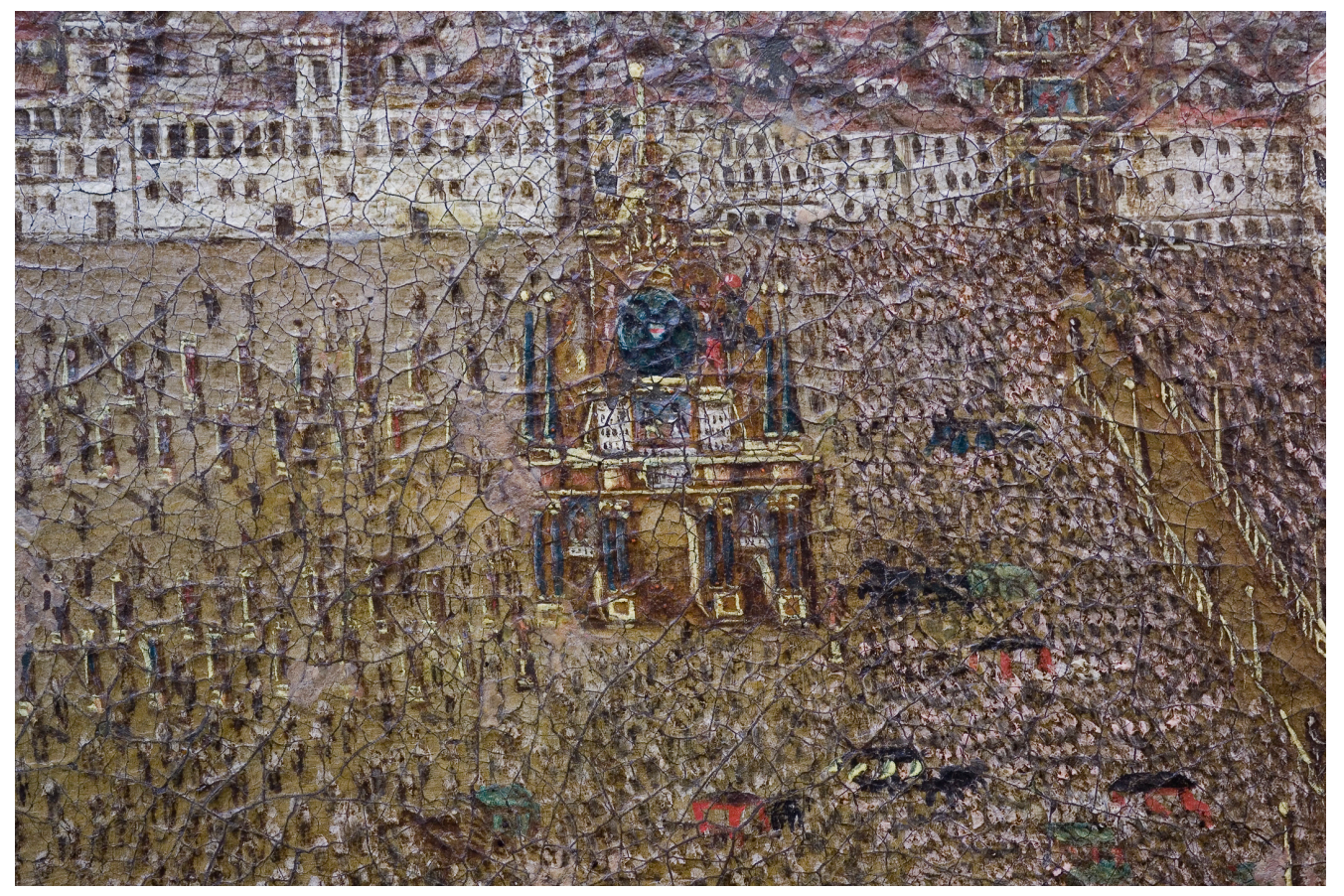

Figure 3 Detail of the Arch of the German Merchants in the Panorama of Lisbon (1613), Oil on Canvas, courtesy of Weilburg Castle.

Creating an artistic impression that would imitate the colours found in other paintings of the period for the re-creation of the ephemera of 1581 might sound tempting. However, these colours do not entirely match what the accounts tell us about the temporary structures of 1581, and the results would at best be creative renditions more suited for a different purpose. ${ }^{15}$ The Charter and Principles reflect architectural conservation theory in emphasising the necessity of

15 I refer here to video games or the film industry, for example. For a case study in which graphics that imitate 'real life' textures and colours could be included, see Laura Fernández-González, 'O modelo digital da pintura Rua Nova: recreando a arquitetura quinhentista de Lisboa', in A cidade global: Lisboa no Renascimento/The Global City: Lisbon in the Renaissance, ed. Annemarie Jordan \& Kate Lowe (Lisboa: Património Nacional, 2017), 78-83. 
making recognisable to viewers any interpretation that impacts the visual appearance of the object.

Notwithstanding the challenges, the process of drawing and modelling was useful in informing other questions of the historical enquiry. The architectural representation of Lisbon's ephemera of 1581, for example, confirmed earlier suggestions that some structures might have been recycled (see the lower body of the arches of the German Merchants both in 1581 and 1619). ${ }^{16}$ The diagrams, architectural plans and 3D model served also to order the information and to chart the existence of some repetition in the festival structures of 1581: for example, representations of Janus appear in prominent locations in both the Arch of the German Merchants and the ephemeral display in the Alfândega (maritime customs) building. These structures were adjacent to each other and Janus was displayed in close proximity in both structures. ${ }^{17}$ The replication of themes here reinforces the notion that this festival was a product of the effort of many agents and that designers from both the royal court and the city participated. ${ }^{18}$

16 Miguel Soromenho, 'Ingegnosi ornamenti: arquitecturas efémeras em Lisboa no tempo dos primeiros Filipes', in Arte Efémera em Portugal, ed. João Castel Branco (Lisboa: Fundação Calouste Gulbenkian, 2001), 21-38.

17 Fernández-González, 'Negotiating Terms', 98-102; and Fernández-González, 'La representación de las naciones', 442.

18 Fernández-González, 'Negotiating Terms', 96. 


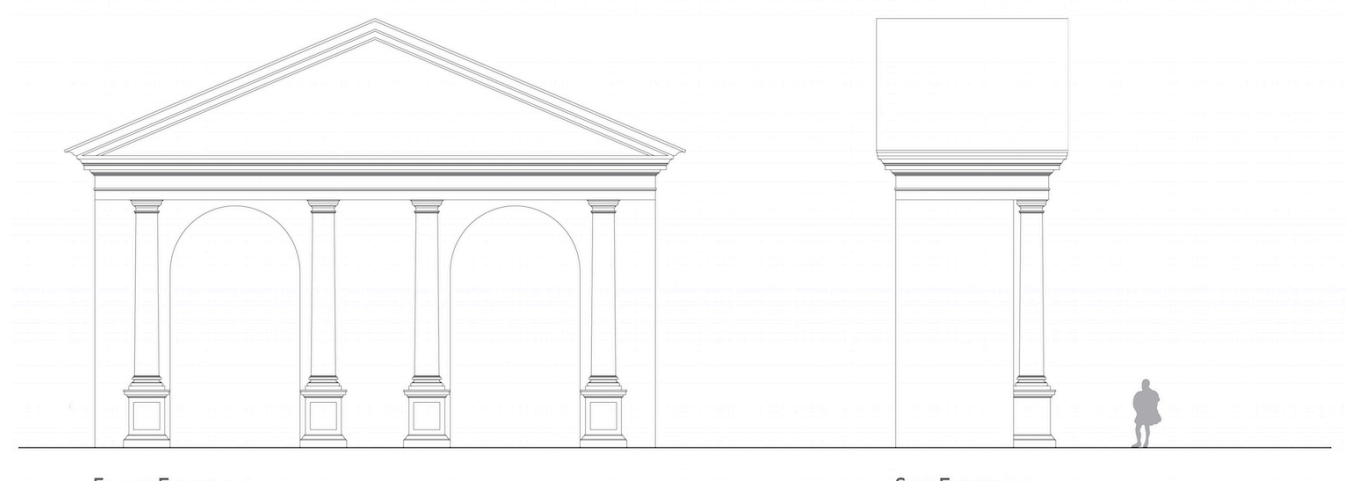

Front Elevation

Side Elevation

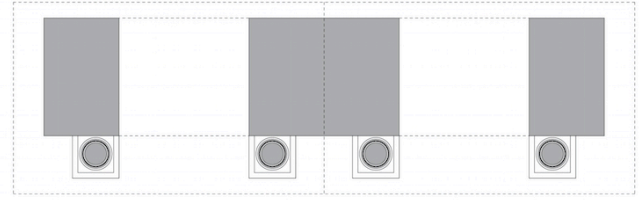

PLAN
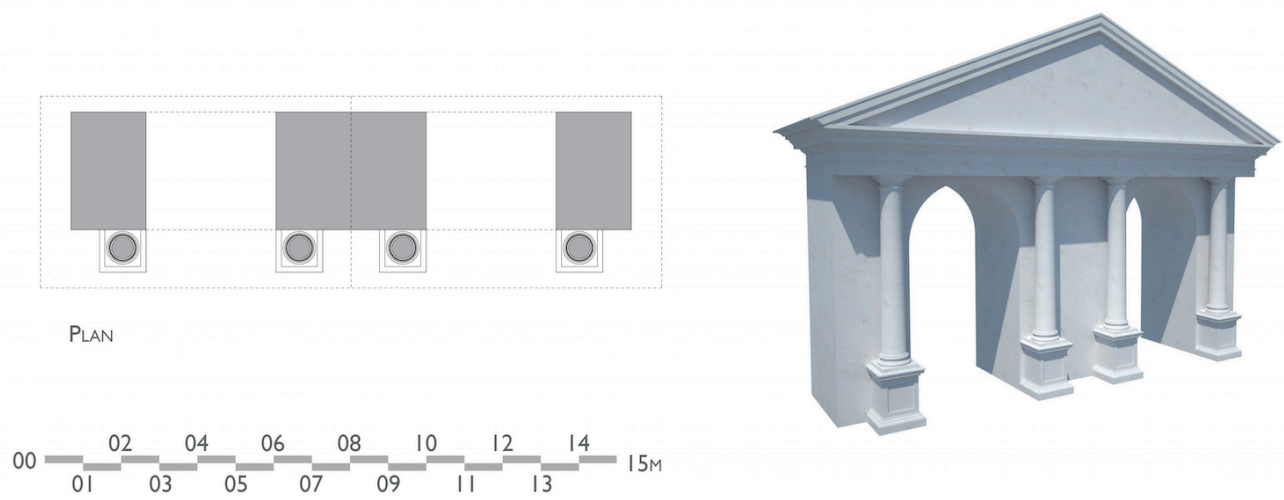

Figure 4 Hypothetical Architectural Drawings and 3D Model of part of the Ephemeral ensemble displayed at the Alfândega in Lisbon in 1581. (c) Author, 2010.

The façade erected in 1581 on the Cais de Alfândega, on Lisbon's riverfront, presented a doubled-arched structure that imitated a classical temple front (see Figure 4). Guerreiro also provided the measurements of architectural elements in the ephemera erected in the Alfândega; however, these are often buried within the convoluted description of the decoration and pageant. This façade was linked to the Arch of the German Merchants via a sequence of alternating statues over pedestals. As Guerreiro explained: 'Era esta fachada 
dividida por dous arcos de ordem dorica, que fingão ser de pedra de cor de claro \& escuro. Cada hum tinha hua columna de cada parte de comprimento de trinta palmos. [...] o friso \& frontispicio que sobião acima.'19 The account describes a twin Doric temple façade with a frieze, pediment and columns (see Figure 4). The colour of the ephemera is described in a rather sketchy fashion: white (claro) and black (a likely imitation of vetted marble). The description also specifies a sequence of alternating statues and obelisks (pyramides) over pedestals:

[...] tinha seys piramides de trinta palmos de altura em igual distancia. Cujos pedestais tinhão dez, todos da misma cor dos portais, com huas bolas nos remates. E entre hus pyramides \& outros avia outros seys pedestais da forma \& altura dos pedestais dos pyramides. Em cada hu dos quaes avia hua estatua de vulto con certas insignias na mão, e letras ao pe, que denotavan a signição dellas. ${ }^{20}$

According to Guerreiro, the scale of the pedestals and obelisks corresponded to that of the columns in the Doric temple front, whilst the proportional systems in the scale of the ephemera reflected Renaissance design ideals. The colour of the statues that alternated with the obelisks also mirrored the claro and oscuro present in the temple. Figure 5 shows an elevation of this façade that renders the measurements found in the accounts. It includes the profile of some of the sculptures to enable identification of their location in the

19 Guerreiro, Das Festas, 13

20 Guerreiro, Das Festas, 13; and Velázquez Salmantino, La Entrada, 121. The scale of what Guerreiro and Velázquez call pyramids corresponds to obelisks in current architectural terminology. 
ephemeral display. Nevertheless, these are indicative profiles and do not portray the form that these statues might have had. The ephemeral composition visually ordered this section of the Terreiro do Paço for the entry of the monarch by transforming the space of the plaza with displays inspired by ancient Roman triumphal culture. ${ }^{21}$

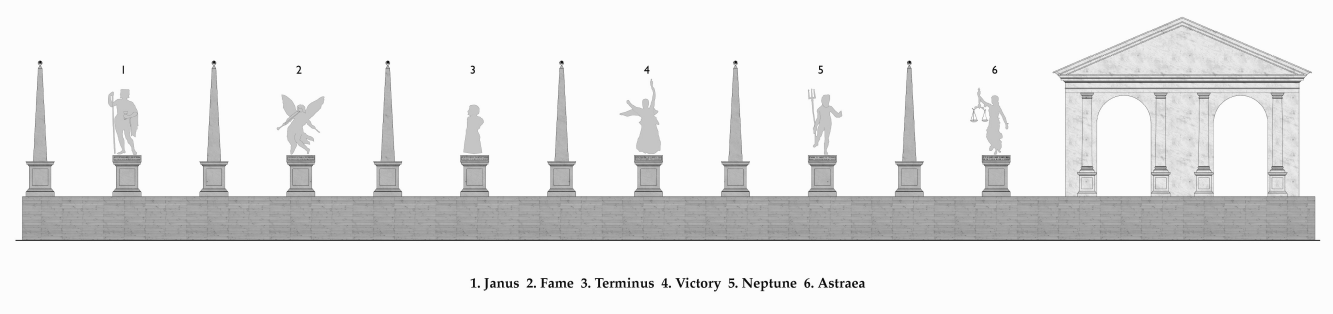

Figure 5 Hypothetical Elevation of part of the Ephemeral ensemble displayed at the Alfândega in Lisbon in 1581. Note the statues outlined are not representative of those displayed at the festival. (C) Author, 2010.

A comparison of the description of the Alfândega structure in the Portuguese and Spanish accounts seems contradictory. Whilst the level of detail of Guerreiro's measurements and the presence of statues indicate that this was a 'built' ephemeral structure, he also mentioned that the decoration of the other façades of the Alfândega building could barely be seen by the participants in the pageant. ${ }^{22}$ Velázquez Salmantino criticized the quality of the ephemera, in which large canvases, mounted in wooden frames (armaçom) and

21 The composition of the façade toward the Tagus echoes the description of the Dii Consentes in the Roman Forum, see Fernández-González, 'La representación de las naciones', 444.

22 Guerreiro, Das Festas, 14-15. 
painted with emblems, had covered the building. ${ }^{23}$ The Spanish writer does not clarify whether the façade facing the River Tagus, which Guerreiro describes as a temporary structure built over a podium, was made of armaçom as well. It seems unlikely that Guerreiro would render the architectural measurements of the façade or mention statues (estatua de vulto) if there had not been a temporary three-dimensional structure. However, if further evidence were to emerge that confirmed the Spanish version, a reinterpretation of the Alfândega display and its digital re-creation would be required.

The analysis of the process of re-creation of the ephemera of 1581 illustrates some of the material, conceptual, ethical and theoretical problems posed by this type of project. At the same time, the recreation project has also furthered our understanding of the festival. As discussed above, the original ephemera would have been profusely decorated; however, if original drawings of the arches were to emerge, the digital re-creations would be useful in identifying them for they show the bare wooden structure described in the accounts. Architectural drawing and 3D modelling are a research method and not a means in themselves, and provide a better understanding of other aspects (spatial, architectural, visual, cultural and political) of the object of study. The possibility of modifying the re-creations as further information emerges makes this digital method useful for historical research. It is crucial, however, that the scope and caveats of the drawings and models are made clear to audiences. ${ }^{24}$ The

23 Velázquez Salmantino, La Entrada, 119.

24 Caroline Bruzelius, 'Digital Technologies and New Evidence in Architectural History' Journal of the Society of Architectural Historians, 76:4 (2017), 436-39. 
similarities of the lower body of the Arch of the German Merchants to subsequent versions of the arch is a useful example for validating Guerreiro's account. However, without contemporary images it is difficult to discern to what extent the rest of the account comes close to the ephemeral structures erected for the fête.

\section{The City as Theatre: Urban Regulations and Streetscapes in Madrid and Valladolid 1565-1608}

The second case study, which focuses on legislation that aimed to regulate the design of residential architecture in Madrid and Valladolid, is an example of the successful application of digital visualisation methods for architectural history research. In this case, the architectural drawings and 3D model developed for the project were instrumental in identifying pertinent early modern visual sources. Sixteenth-century policy on domestic architecture design issued in Madrid between 1565 and 1584 aimed to regulate residential architecture in the city. At this time, the city was witnessing a boom in architectural activity, as incoming residents came to Madrid attracted by the presence of Philip II of Spain, and the wealth of his court. With the arrival of the court came the Regalia de Aposento, which obliged homeowners to host members of the court. ${ }^{25}$ Hosting duties were not well received by many and the quality of residential architecture suffered as developers tried to avoid the aposento levy. Casas a la malicia, a kind of poorly constructed housing which deliberately aimed to flout the hosting

25 Francisco José Marín Perellón, Planimetría general de Madrid y Regalía de Aposento (Madrid, 1989). 
duties, proliferated in Madrid. The king and local authorities sought to palliate issues with accommodation and above all to improve the quality of the residential architecture in the city through urban regulations. Three pieces of legislation issued in 1565, 1567 and 1584 sought to solve the problem by enacting a set of requirements for homeowners wishing to reform or build a house. The incentives attached to the legislation, such as the exemption from hosting duties for a number of years, intended to transform the streetscapes of Madrid and also later Valladolid. ${ }^{26}$

Furthermore, the legislation offers a glimpse of the domestic architecture and streetscapes that the court and city council had envisioned for Madrid (and subsequently Valladolid) as the court capital, which required architecture to be suitable to cater for the ceremonial needs of its population. Domestic architecture in this period was intended to act as an embellished and orderly backdrop to the urban rituals performed in streets and other spaces of social encounter. It is not surprising that both cities embarked on initiatives that aimed to adapt the urban fabric to the needs of the calendric and non-calendric urban festivals and performances. ${ }^{27}$ The regulations issued in both cities promoted a house prototype that was fundamentally uniform in terms of façade design and construction

26 See Claudia W. Sieber, 'The Invention of a Capital: Madrid and the First Reform of Madrid', Doctoral dissertation (John Hopkins University, 1985); and Alfredo Álvar Ezquerra, El nacimiento de una capital europea: Madrid entre 1561 y 1601 (Madrid: Turner, 1989).

27 The literature has discussed extensively the relationship between urban reform, architectural design and festival culture. The reconstruction of Valladolid after the fire of 1561 is a good example, in which 'The architectural layout of the streets, in particular the newly built Plaza Mayor, was now ideal for religious processions [... and] a perfect setting for public celebrations' see Ilenia Colón Mendoza, The Cristos yacentes of Gregorio Fernandez: Polychrome Sculptures of the Supine Christ in Seventeenth-century Spain (Aldershot: Ashgate, 2015), 2. 
materials and technologies. Only the dimensions of the houses varied, as was also reflected in their internal distribution of space. In addition, the fact that the real cédula of 1584 only applied to a specific area of Madrid in the vicinity of the Alcázar further highlights the strong relationship between the court, royal festivals and the improvement of streetscapes. ${ }^{28}$ Façade walls had to be well built and aligned to the street, with a minimum height of six metres including the two floors and the podium (only around a metre higher in the cédula of 1584). Façades were to be a minimum of twelve and a half metres long in 1565, at least nine metres in 1567 and just under twenty-one metres in 1584 .

A drawing of the façade prototype would also be shown to developers wishing to construct houses, although examples of such drawings have not yet been identified. These drawings would have been the visual standard and guide for developers. Figure 6, for example, represents a number of possible elevations of façades recreated under the real cédula of 1584.

28 For the reales cédulas of 1565 and 1584, see Andrés Díez Navarro, Alegación fiscal por el derecho y regalías de la de Real Aposento de Corte (Madrid: s.l., c.1740), 23-26 and 2628 . For the real provisión of 1567, see Francisco Iñíguez Almech, 'Límites y ordenanzas de 1567 para la Villa de Madrid,' Revista de la Biblioteca, Archivo y Museo, XXIV (1955), 3-38. 

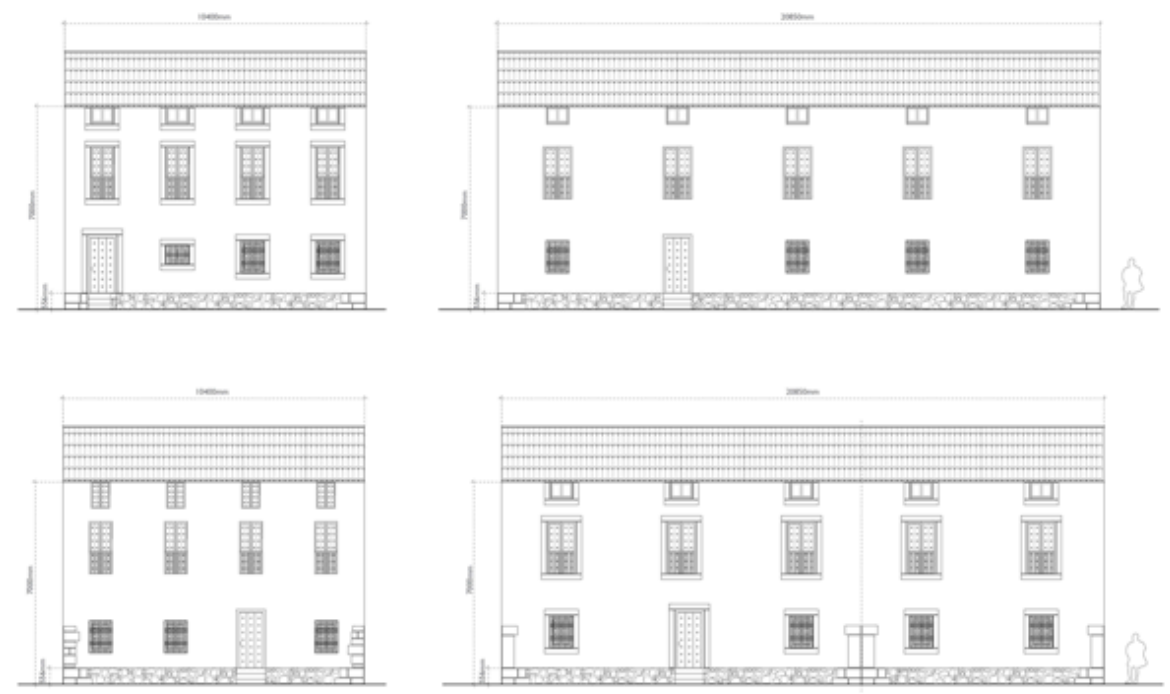

Figure 6 Hypothetical Re-creation of Façade Elevations of the Houses promoted in the Real Cédula issued in Madrid in 1584. (C) Author, 2011.

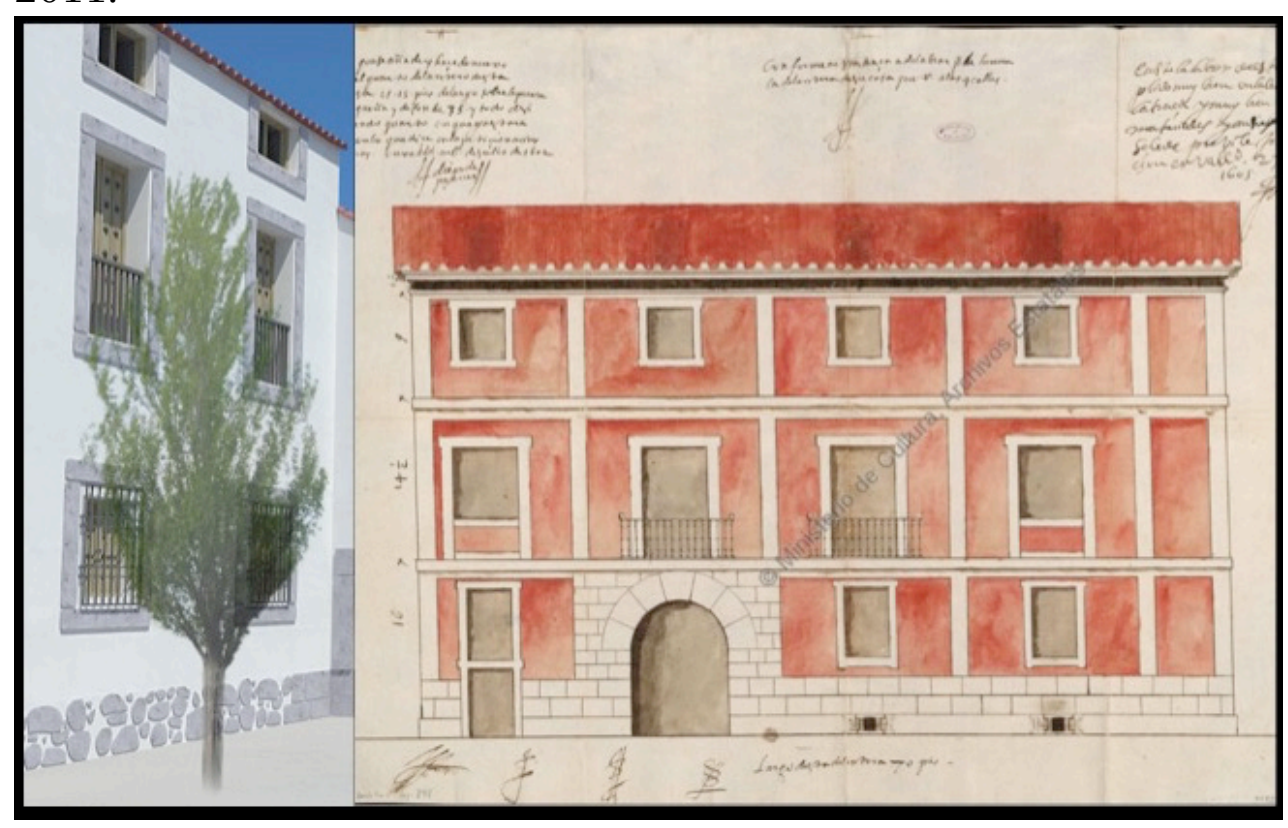

Figure 7 Hypothetical 3D model of a posible house built under the aegis of the Real Cédula issued in Madrid in 1584 (left-hand side) and Francisco de Mora's design for a residence in Valladolid in 1604 
(right-hand side). (C) Still 3D model author, 2011 and Mora's drawing courtesy of the Archivo General de Simancas.

The façades might have been painted in different colours, or built entirely in stone and others in brick, although this is not detailed in the legislation. In this representation, I have portrayed the information described in the sources. The Casa de las Siete Chimeneas and other surviving sixteenth-century buildings in Madrid have been used for inspiration for the windows, balconies and doors. The visual re-creations, however, do not necessarily represent the houses erected under the legislation issued in the period, but instead the requirements outlined in the law. ${ }^{29}$ The drawings and models that represent visually the architectural measurements of the house prototype specified in the law were not made for display but to better understand the architectural design proposed. The elevations are also useful in considering theoretical understanding of theatre, performance and urban aesthetics in the Iberian world. The street view, a still taken from a 3D model, on the left-hand side of Figure 7, however, is a fabrication, a tool for research.

Streetscapes in renaissance and baroque urbanism would have boasted a range of buildings (including palatial and religious edifices). The buildings would have had different materials, textures, and heights, and also different styles of façade. Through drawing and

29 José Antonio Martínez Bara, Licencias de Exención de Aposento del Madrid de Felipe II (Madrid: Instituto de Estudios madrileños, 1962); and Juan Luis González García, 'De ornato y policía en Madrid: casas principales y ordenación viaria en el Renacimiento,' Anales de Historia del Arte, 7 (1997), 99-122. Note the building permits do not include images of the houses erected. 
modelling it was possible to think spatially and visually about the city that the promoters of the law might have imagined.

The hypothetical re-creations of residential architecture in Madrid crucially served also to identify a drawing of a house that was very similar to the digital re-creations developed (compare images in Figure 7). In 1602, one of the former architects to Philip II, Francisco de Mora (c.1553-1610), designed a house with similar characteristics in Valladolid. ${ }^{30}$ The design of this house in Valladolid is inspired by the reductive classicism implemented in royal buildings during Philip II's reign. The urban regulations to improve domestic architecture were then also applicable in Valladolid and the requirements of the legislation were fundamentally the same in both cities. Elevation drawings show that the measurements of houses in Valladolid were very close to those erected under the aegis of the order of 1584 for Madrid. The identification of the drawing of the house in Valladolid was made possible this time thanks to the application of architectural drawing and 3D modelling as a research tool.

\section{Thinking through drawing}

Drawing is a form of thinking, just as writing is for historians and scholars in the Humanities. Brian Edwards, among numerous architects and artists before and after him, has explored the benefits that freehand drawing have for understanding architecture. Edwards' work is of interest in that he theorises on the role of

30 Archivo General de Simancas, Cámara de Castilla, Leg. 893, Memorandum de Pedro de Herrera y Lintorne sobre la exención del aposento, Valladolid, 27 de mayo de 1604. 
sketching vis-à-vis architectural models, CAD or photography. ${ }^{31}$ With the advent of visualisation in digital heritage, particularly the possibility of creating virtual environments via accessible software suites, researchers are increasingly incorporating digital tools for visual and spatial analysis. I agree that sketching, freehand and digital drawing and 3D modelling aid thinking and have the potential to advance research questions. Through the analysis of two case studies in this article it has been possible to discuss notions of authenticity in conservation theory and the limits of representation. Both projects have also advanced knowledge of the relationship between urbanism and festivals. The usefulness of drawing and modelling is manifest.

One of the major concerns that the field has is the proliferation of images and virtual models with impressive graphics, in which audiences would have difficulties in distinguishing speculative data. This is particularly concerning with respect to current trends in the marketization of heritage and the post-truth era. ${ }^{32}$ The debate echoes some early discussions on architectural conservation that had authenticity at its core. The restoration projects carried out by the architect Eugène Viollet-le-Duc (1814-1879) on prominent medieval buildings sought not only to consolidate and maintain what had remained but also to 'complete' and, when required, make 'stylistic corrections'. The generation that followed, including William Morris and John Ruskin, criticised the practice. In the same vein, the art

31 Brian Edwards, Understanding Architecture Through Drawing (New York: Taylor \& Francis, 2008 [1994]).

32 Aylin Orba li, 'Conservation Theory in the Twenty-first Century: Slow Evolution or a Paradigm Shift?', Journal of Architectural Conservation, 23:3 (2017), 157-70. 
critic and historian Cesare Brandi (1906-1988) advocated a conservation practice that consolidated structures but avoided the inclusion of 'creative interpretations' or 'corrections'. Brandi's theories were instrumental in shaping the discipline. ${ }^{33}$

Authenticity is also at the core of current debates on the use of visualisation in digital heritage, particularly if such visualisation aims to re-create long lost historic urban environments. As we have seen above, the application of drawing and 3D modelling has advanced our knowledge of Philip II's ceremonial entry into Lisbon in 1581, even if the resulting images and 3D model are hypothetical. The application of the same methods of 'translation' of verbal sources into visual form has likewise proven effective in furthering our knowledge of residential architecture in Habsburg Madrid and Valladolid. Virtual re-creations are a non-invasive research tool whose impact cannot be compared to major architectural interventions in buildings. Nevertheless, though it is imperative to make use of the full range of methods available to advance knowledge, I would argue that we must also act with caution and painstakingly apply conservation theory and practice to digital visualisation projects.

33 Jukka Jokilehto, History of Architectural Conservation (New York: Routledge, 2007).

* Disclosure Statement: No potential conflict of interest was reported by the author. 